\title{
Genoprotective and Genotoxic Effects of Thymoquinone on Doxorubicin-Induced Damage in Isolated Human Leukocytes
}

\author{
Ramadan I Al-Shdefat ${ }^{1}$, Mohamed A Abd-EIAziz ${ }^{2 *}$ and Fahad I Al-Saikhan ${ }^{2}$ \\ ${ }^{1}$ Department of Pharmaceutics, ${ }^{2}$ Department of Clinical Pharmacy, College of Pharmacy, Salman Bin Abdulaziz University, \\ Riyadh, Al-kharj 11942, Saudi Arabia \\ *For correspondence: Email: m.abdelmotaal@sau.edu.sa
}

\begin{abstract}
Purpose: To investigate the potential genoprotective effects of thymoquinone (TQ) on the cytotoxicity and genotoxicity-induced by doxorubicin (DXR), a key chemotherapeutic drug.

Methods: Isolated human peripheral leukocytes were treated with varying concentrations of TQ (5.0, 10.0 , or $20.0 \mu \mathrm{M})$ alone or in combination with DXR $(0.15 \mu \mathrm{g} / \mathrm{mL})$. Comet assays and apoptotic cell studies were performed to evaluate the effect of TQ on the cytotoxicity and genotoxicity-induced by DXR.

Results: TQ treatment, alone, $(5.0,10$, or $20 \mu \mathrm{M})$ increased DNA damage index (DI) in a concentrationdependent manner $(0.64 \pm 0.09,0.84 \pm 0.07$, and $0.93 \pm 0.06$, respectively). $D X R(0.15 \mu \mathrm{g} / \mathrm{mL})$ increased DI (1.67 \pm 0.09$)$ compared with no treatment $(0.34 \pm 0.03)$. However, when TQ was administered with DXR, DI was significantly reduced $(0.96 \pm 0.04,0.80 \pm 0.05$, and $0.79 \pm 0.04)$ compared with DXR alone (1.67 \pm 0.09$)$. Similarly, apoptotic cells decreased $(10.8,11.8$ and 14.2\%) compared with that induced by DXR alone (27.6\%).

Conclusion: $T Q$ can be used as a genoprotective agent against DXR-induced genotoxicity. The dual behavior of TQ observed in this study is dose-dependent and therefore its mechanism of action needs to be clarified in future studies.
\end{abstract}

Keywords: Thymoquinone, Genotoxicity, Genoprotection, Doxorubicin, Apoptotic, Oxidative stress, DNA damage index

Tropical Journal of Pharmaceutical Research is indexed by Science Citation Index (SciSearch), Scopus, International Pharmaceutical Abstract, Chemical Abstracts, Embase, Index Copernicus, EBSCO, African Index Medicus, JournalSeek, Journal Citation Reports/Science Edition, Directory of Open Access Journals (DOAJ), African Journal Online, Bioline International, Open-J-Gate and Pharmacy Abstracts

\section{INTRODUCTION}

Nigella sativa L. seeds (Ranunculaceae), commonly known as black seed, are used as a traditional Arab herbal medicine for treating many diseases and ailments [1, 2]. Thymoquinone (TQ), the main essential oil of $N$. sativa has been intensively studied and is reported to possess antioxidant and anti-inflammatory properties [3,4] and to decrease the nephrotoxicity of some chemotherapeutic agents [5].
The hepatoprotective effect of TQ was reported in a study that used isolated rat hepatocytes in suspension culture that were treated with tertbutylhydroperoxide (TBHP) [6]. The hepatoprotection afforded by $T Q$ was equal to that of silybin, a known hepatoprotective agent with antioxidant properties. Specifically, TQ prevented the leakage of certain hepatic enzymes (e.g., alanine transaminase [ALT], aspartate transaminase [AST], and co-enzyme glutathione [6,7]. 
There is a wide consensus in cancer research that TQ exerts promising anticancer activity in both in vitro and in vivo models [8]. It is effective against several types of cancer cell lines, and classical hallmarks of apoptosis such as chromatin condensation, translocation of phosphatidyl serine across the plasma membrane, and DNA fragmentation have been documented in TQ-treated cells [9,10]. Moreover, TQ was found to have anticancer activity against breast cancer cells through its potential effect on the peroxisome proliferator-activated receptors (PPARs) [11].

Cytotoxic and genotoxic effects of TQ have also been demonstrated in primary rat hepatocyte cultures [12]. For example, one study showed that TQ induced significant anti-proliferative effects at $20 \mu \mathrm{M}$ and acute cytotoxicity at higher concentrations [13]. Moreover, it has been reported that $\mathrm{TQ}$ induces $\mathrm{p} 53$-independent apoptosis through activation of caspase-8 and other caspases involved in the caspase cascade [14]. Based on the existing evidence, we analyzed the in vitro genotoxic and genoprotective properties of $\mathrm{TQ}$ on doxorubicin (DXR)-induced genotoxicity in isolated cultured human leukocytes using comet assays.

\section{EXPERIMENTAL}

\section{Cells and medium}

Human peripheral blood was collected in heparinized vials from five healthy donors (25 30 years old). Leukocytes were isolated and cultured in RPMI-1640 medium (Sigma-Aldrich, St. Louis, MO, USA) supplemented with $20 \%$ fetal calf serum (Cultilab, Campinas, SP, Brazil), streptomycin $(10 \mu \mathrm{g} / \mathrm{mL})$ penicillin $(5 \mu \mathrm{g} / \mathrm{mL})$, and $2 \%$ phytohemagglutinin (Life Technologies, Carlsbad, CA, USA). Cells were cultured at 37 ${ }^{\circ} \mathrm{C}$ in culture flasks containing $5 \mathrm{~mL}$ complete medium.

The experimental protocols were approved by Research Ethics Committee (REC) of College of Pharmacy, Salman Bin Abdulaziz University, Alkharj, Saudi Arabia. Written informed consent was obtained from each blood donor prior to their participation.

\section{Chemicals}

All chemicals and reagents used in the present study were of the highest analytical grade from Sigma-Aldrich. DXR was purchased as $10-\mathrm{mL}$ vial ready for infusion (Adriamycin $®$ Pharmacia), with a concentration of $2 \mathrm{mg} / \mathrm{mL}$.

\section{Cell culture treatments}

Different concentrations of TQ (Sigma-Aldrich; $5.0,10.0$, or $20.0 \mu \mathrm{M}$ ) were tested in combination with DXR in preliminary experiments; concentrations of TQ above $20 \mu \mathrm{M}$ were cytotoxic and significantly reduced cell viability. The concentration of DXR $(0.15 \mu \mathrm{g} / \mathrm{mL})$ was similarly defined in preliminary experiments (data not shown) and in our previous study that quantified numbers of chromosomal aberrations [15]. Cytotoxic and cytostatic effect of the combined treatment can mimic antimutagenicity as they interfere with the appearance of mutant cells.

The isolated leukocyte cell cultures were treated either with vehicle (positive control) or DXR (Negative control). Three types of TQ treatment were assessed for their effects on DXR-induced damage in cells. After incubation for $24 \mathrm{~h}$, the cell cultures were treated with TQ either simultaneously, $2 \mathrm{~h}$ before, or $2 \mathrm{~h}$ after DXR treatment. After each treatment, DXR and TQ remained in the culture media until cell harvest. After $24 \mathrm{~h}$ of DXR treatment, cells were harvested and assessed for cell viability, apoptosis, and DNA damage to individual cells (comet assay).

\section{Comet assay}

A 300- $\mu \mathrm{L}$ aliquot from each culture was taken 48 hours after incubation to test for cell viability by trypan blue exclusion and for use in the alkaline version of the comet assay [16]. The cell suspension $(300 \mu \mathrm{L})$ was centrifuged for $5 \mathrm{~min}$ at $500 \mathrm{rpm}$ in a refrigerated microcentrifuge. The resulting pellet was homogenized with $80 \mu \mathrm{L}$ of a low melting point agarose $(0.5 \%)$, spread onto microscope slides pre-coated with a normal melting point agarose $(1.5 \%)$, and covered with a coverslip. After $5 \mathrm{~min}$ at $4{ }^{\circ} \mathrm{C}$, the cover slip was removed and the slides were immersed in cold lysis solution for $24 \mathrm{~h}$. After lysis, the slides were placed in an electrophoresis chamber and covered with electrophoresis buffer for $20 \mathrm{~min}$ to facilitate DNA winding. The electrophoresis continued for $20 \mathrm{~min}(25 \mathrm{~V}$ and $300 \mathrm{~mA}$ ). Next, the slides were submerged for $15 \mathrm{~min}$ in a neutralization buffer, dried at room temperature, and fixed in $100 \%$ ethanol for $5 \mathrm{~min}$. Immediately before analysis, slide staining was performed using ethidium bromide $(20 \mu \mathrm{g} / \mathrm{mL})$. Slides were prepared in duplicate, and 100 cells were screened per sample (50 cells from each slide) using a fluorescent microscope (ZEISS, Oberkochen, Germany). According to fragment migration, the nuclei were visually classified as: 0 
(no damage), 1 (minimal damage with a short tail length smaller than the diameter of the nucleus), 2 (moderate damage with a tail length one or two times the diameter of the nucleus), 3 (significant damage with a tail length between two and a half to three times the diameter of the nucleus), and 4 (significant damage with a long tail of damage greater than three times the diameter of the nucleus). DNA damage was assessed using software as described in the comet test manual (Fig 1).

\section{Morphological characterization of normal, apoptotic, and necrotic cells}

We determined the frequencies of normal, apoptotic, and necrotic cells in cells treated with TQ $2 \mathrm{~h}$ before DXR treatment. We applied $2 \mu \mathrm{L}$ of fluorescein diacetate staining solution dissolved in DMSO $(15 \mu \mathrm{g} / \mathrm{mL})$, propidium iodide (5 $\mu \mathrm{g} / \mathrm{mL}$ ), and Hoechst $33342(2 \mu \mathrm{g} / \mathrm{mL}$ ) (all from Sigma) to a $100 \mu \mathrm{L}$ cell suspension. For the three independent experiments, 500 cells per treatment were analyzed with an epifluorescence microscope. An intact and bluestained nucleus was considered normal, a fragmented and a blue nucleus was considered apoptotic, and a red nucleus was considered necrotic.

\section{Statistical analysis}

Statistical analysis was performed using the Kruskal-Wallis one-way method of variance (six independent experiments were analyzed) followed by Student-Newman-Keuls tests with $95 \%$ confidence intervals.

\section{RESULTS}

Figure 2 shows the comet assay results and the DNA damage index (DI) findings for human leukocytes treated with DXR $(0.15 \mu \mathrm{g} / \mathrm{mL})$ and different concentrations of $\mathrm{TQ}(5.0,10$, and 20 $\mu \mathrm{M})$. DXR and TQ (5.0, 10, and $20 \mu \mathrm{M})$ applied separately increased the DI. However, compared to DXR treatment alone, the combined treatment of DXR and TQ (whether before or after) significantly reduced both $\mathrm{DI}$ and the frequency of comet-positive cells. The reduction was between $96 \%$ and $97.5 \%$ and was not dosedependent.

As shown in Table 1, TQ treatment $(5,10$, and $20 \mu \mathrm{M})$ significantly reduced the number of apoptotic cells induced by DXR $(0.15 \mu \mathrm{g} / \mathrm{mL})$ and consequently increased the number of viable cells. The most significantly protective TQ concentration was $5.0 \mu \mathrm{M}$.
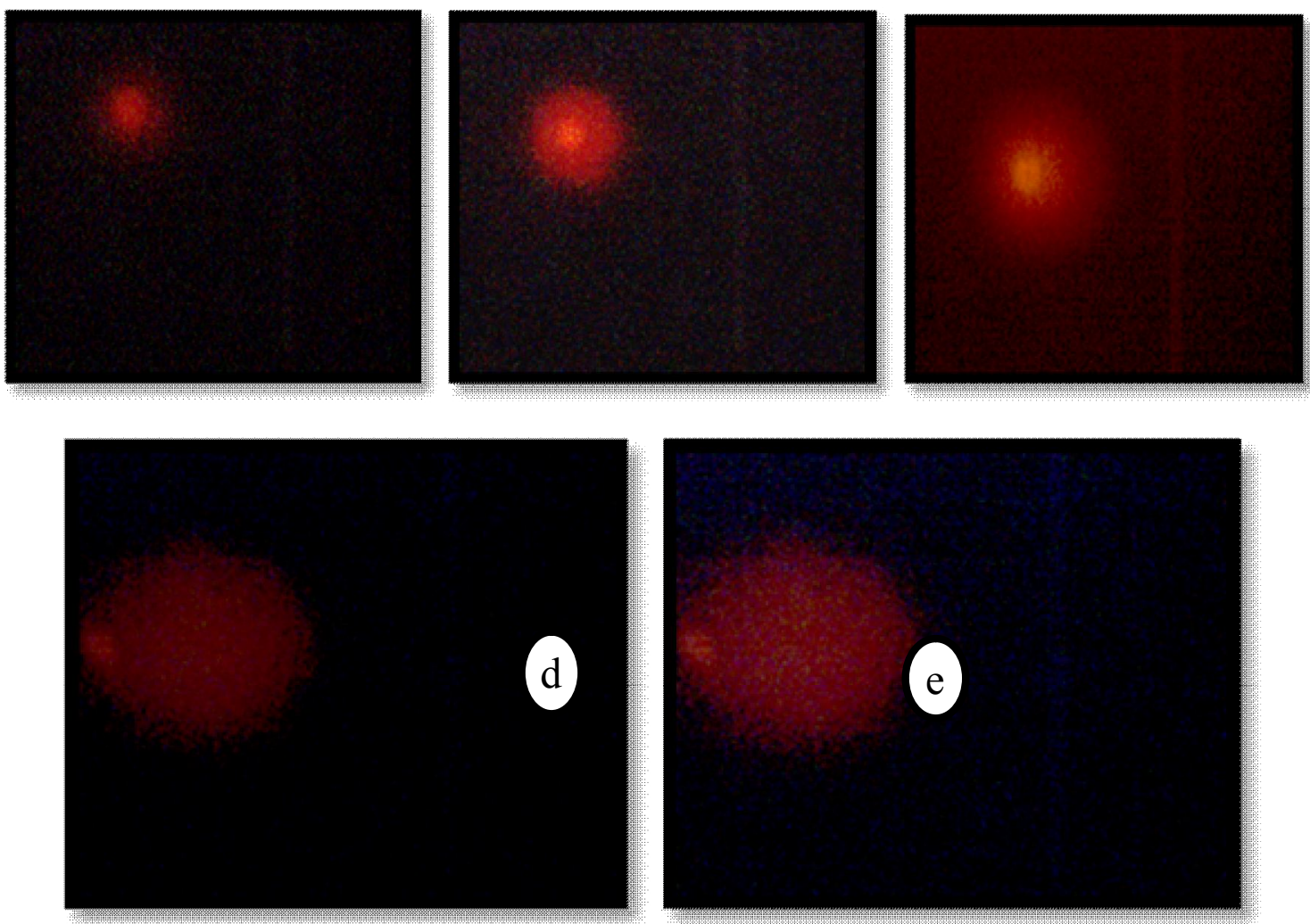

Fig. 1: Different levels of DNA damage in human leukocytes in the comet assay: (a) none, class 0 ; (b) low, class 1 ; (c) moderate, class 2; (d) high, class 3; and (e) total, class 4 


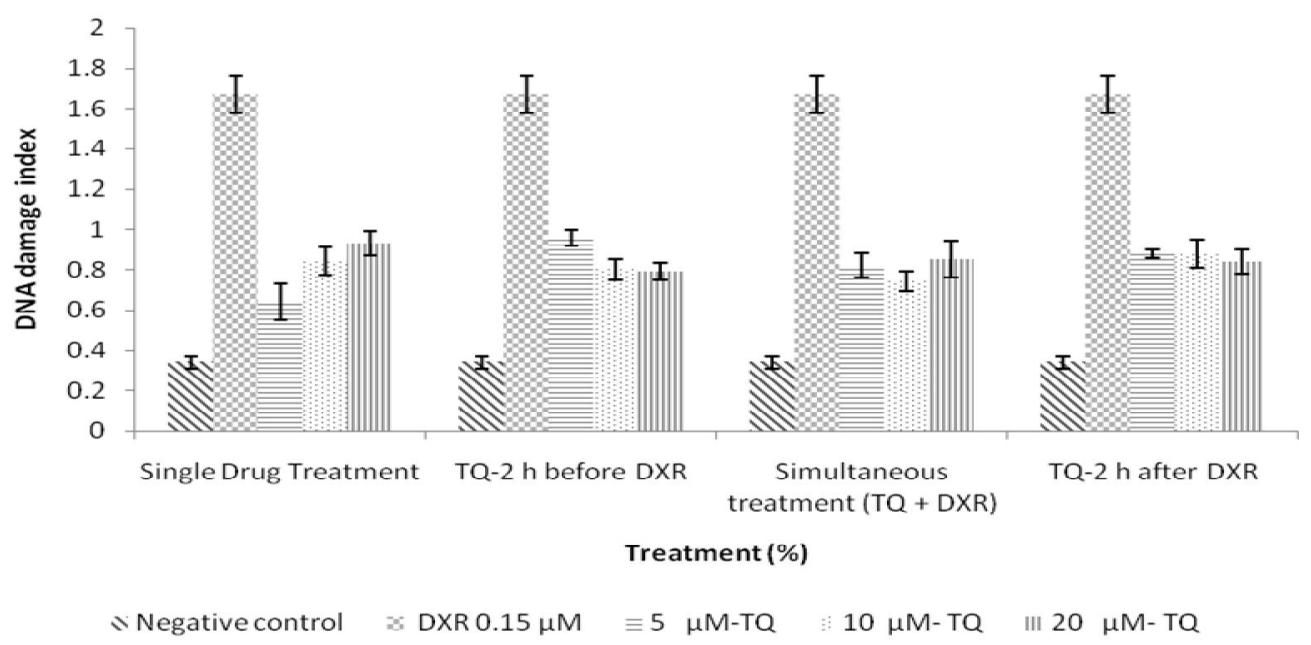

Fig. 2: Results of the comet assay assessing the effect of TQ on human leukocytes treated with DXR

Table 1: Apoptotic cells observed in isolated human leukocytes following different treatments with TQ and/or DXR

\begin{tabular}{lcccc}
\hline Treatment (\%) & $\begin{array}{c}\text { Scored cells } \\
(\mathbf{N})\end{array}$ & $\begin{array}{c}\text { Viable cells } \\
(\%)\end{array}$ & $\begin{array}{c}\text { Apoptotic } \\
\text { cells (\%) }\end{array}$ & $\begin{array}{c}\text { Necrotic } \\
\text { cells (\%) }\end{array}$ \\
\hline Single drug treatment & & & & \\
Control & 1500 & 96.9 & 2 & 1.1 \\
DXR & 1500 & 69 & $27.6^{\mathrm{a}}$ & 3.4 \\
$5 \mu \mathrm{M} \mathrm{TQ}$ & 1500 & 94.2 & $4.8^{\mathrm{a}}$ & 1 \\
$10 \mu \mathrm{M}$ TQ & 1500 & 92.6 & $5.9^{\mathrm{a}}$ & 1.5 \\
$20 \mu \mathrm{M} \mathrm{TQ}$ & 1500 & 91.6 & $7.3^{\mathrm{a}}$ & 1.1 \\
Concurrent treatment (TQ + DXR) & & & \\
$5 \mu \mathrm{M}$ TQ + DXR & 1500 & 88.4 & $10.8^{\mathrm{b}}$ & 0.8 \\
$10 \mu \mathrm{M}$ TQ + DXR & 1500 & 86.6 & $11.8^{\mathrm{b}}$ & 1.6 \\
$20 \mu \mathrm{M}$ TQ + DXR & 1500 & 84.2 & $14.2^{\mathrm{b}}$ & 1.6 \\
\hline
\end{tabular}

A total of 1500 cells were scored in each one of the three replicates; doxorubicin (DXR) was applied at a concentration of $0.15 \mu \mathrm{g} / \mathrm{mL}$; ${ }^{a} p<0.05$ compared with negative control (vehicletreated); ${ }^{b} p<0.01$ compared with positive control (DXR)

\section{DISCUSSION}

N. sativa has been traditionally used to treat inflammations, liver disorders, and arthritis. Experimentally, it has been demonstrated that $N$. sativa extracts and TQ, the main constituent of its volatile oil, possess antioxidant, antiinflammatory, hepatoprotective, and genoprotective properties [12,15].

The present study investigated the genoprotective and genotoxic effects of $T Q$ alone and in combination with DXR. DXR is a potent genotoxic anticancer drug that generates undesirable effects in healthy cells. We observed that cells treated with $\mathrm{TQ}$ alone exhibited cytotoxic effects in a concentration-dependent manner; with a significant increase in the percentage of necrotic cells at $5.0 \mu \mathrm{M} \mathrm{TQ}$. Furthermore, TQ also induced concentrationdependent genotoxic effects in leukocyte cultures, including an increase in DNA DI and a greater percentage of apoptotic cells, which was concentration-dependent. We found that $40 \mu \mathrm{M}$ $\mathrm{TQ}$ and higher concentrations (data not shown) caused severe cytotoxic effects in the cultures and were lethal to leukocytes.

These results are consistent with previous reports that showed that high TQ doses deplete cellular GSH [4]. Similarly, TQ has been reported to be a pro-apoptotic agent in variety of cell types, including cells of hematopoietic origin [17]. It has been suggested that TQ activates p53, and reduces anti-apoptotic protein concentration of $\mathrm{Bcl}-2$ [18].

In this study, we employed DXR as the DNA damaging agent. DXR is a recognized topoisomerase II poison that generates reactive oxygen species (ROS) via two different routes of free radical formation. The first involves a nonenzymatic reaction of DXR with iron to form a stable complex, which reacts with oxygen to form superoxide anions, hydrogen peroxide, and hydroxyl radicals. The second involves formation 
of highly reactive semiquinone intermediates through redox modifications [19]. Cell cultures were treated with DXR after $24 \mathrm{~h}$, when most of the stimulated leukocytes were in the middle of $S$ phase. It is noteworthy that $\mathrm{TQ}$ treatment alone $(5.0,10.0$, and $20.0 \mu \mathrm{M})$ increased DNA damage index (DI) and apoptotic cells. Despite these significant genotoxic effects, all concentrations of $\mathrm{TQ}$ effectively reduced the genotoxic and clastogenic effects of DXR.

Whereas most of the comets observed following DXR treatment belonged to classes 2, 3, and 4, the TQ-treated cultures exhibited predominantly class 1 comets. It is noteworthy that the protective effects of TQ demonstrated here did not occur in a dose-dependent manner. TQ equally reduced the DXR-induced damage at the lowest and highest concentrations tested.

A similar "dual behavior" was also observed with vitamin $\mathrm{C}$, which exhibited both pro- and antioxidative activities by decreasing cell death, membrane damage, and lipid peroxidation subsequent to oxygen exposure. This dual role is probably due to its opposing action on two types of oxidative stress [20]. TQ is metabolized in vivo by cellular oxidoreductasees to hydroquinones or semiquinones radicals leading to production of ROS. These radicals may be responsible for the adverse effect of aqueous $N$. sativa extract on liver hepatocytes [20].

TQ also partially prevented DXR-induced oxidative damage in the cardiac tissue of rats supplemented with a TQ-enriched diet [21]. It has been suggested that superoxide scavenging and anti-lipid peroxidation partially explain the protective effect of TQ against DXR-induced cardiotoxicity [22]. Recently, other mechanisms related to $\mathrm{TQ}$ antioxidant properties have been proposed to explain the chemo-protective effects of TQ. TQ attenuated the secretion of proinflammatory cytokine, TNF- $\alpha$ in rat serum of cyclophosphamide-induced pulmonary injury $[23,24]$.

The genoprotective effect and genotoxic effect of $T Q$ may be related to $T Q$ quinone structure. TQ undergoes one or two electron reductions by cellular reductases. One-electron reduction results in the formation of semiquinones, which are converted to ROS when they react with molecular oxygen [20]. Two-electron reductions produce the antioxidant hydroquinone [23]. This obligatory two-electron reduction competes with the one-electron reduction of quinones and protects cells against oxidative stress [25]. Both TQ and dihydrothymoquinone (DHTQ) are potent superoxide anion scavengers and general free radical scavengers and prevent lipid peroxidation [26]. Interestingly, the in vitro antioxidant protection afforded by DHTQ may be greater with low TQ concentrations [27]. In contrast to the antimutagenic anti-oxidant effects reported in the present study in DXR- and TQ-treated lymphocytes, other researchers found that TQ increased necrotic cells at concentrations between 2.5 and $20 \mu \mathrm{M}$ and caused genotoxicity at concentrations more than $1.25 \mu \mathrm{M}$ [15]. However, we did observe this genotoxic effect in the present study when TQ was administered alone.

Regarding the timing of the supplementation with $\mathrm{TQ}$, the present results showed that pre-, post-, or simultaneous treatment equally reduced the DXR-induced genotoxic effects at all tested concentrations of TQ. Similar results were obtained in lymphocyte cultures treated with vitamin C, a potent antioxidant, before, simultaneously, or after DXR treatment [28]. TQ exerts protective effect based on different mechanisms. TQ is involved in antioxidant defense and modulates the response of DNA repair factors and p53 expression. In the present work, only the lowest concentration of TQ was clastogenic and able to reduce DXR-induced damage. The other tested TQ concentrations exhibited some genotoxic effects. However, when applied alone without genotoxic agents, they also reduced the DNA damage induced by DXR.

\section{CONCLUSION}

TQ has genoprotective effects in low dose but can be genotoxic at high concentrations. Therefore, it is recommended that TQ dose should be modulated to achieve the lowest dose that protects against genetic damage with the least toxicity.

\section{ACKNOWLEDGEMENT}

The authors gratefully acknowledge the Deanship of Scientific Research, Salman Bin Abdulaziz University, Al-kharj, Saudi Arabia (Project no. 3H/1433), for providing financial support.

\section{REFERENCES}

1. Abu-Irmaileh BE, Afifi FU. Herbal medicine in Jordan with special emphasis on commonly used herbs. J Ethnopharmacol 2003; 89: 193-197.

2. Lev E, Amar Z. Ethnopharmacological survey of traditional drugs sold in Israel at the end of the 20th century. J Ethnopharmacol 2000; 72: 191-205. 
3. El Gazzar M, El Mezayen R, Marecki JC, Nicolls MR, Canastar A, Dreskin SC. Anti-inflammatory effect of thymoquinone in a mouse model of allergic lung inflammation. Int Immunopharmacol 2006; 6: 11351142.

4. Houghton PJ., Zarka R, de las Heras B, Hoult JR. Fixed oil of Nigella sativa and derived thymoquinone inhibit eicosanoid generation in leukocytes and membrane lipid peroxidation. Planta Med 1995; 61: 33-36.

5. El-Abhar HS, Abdallah DM, Saleh S. Gastroprotective activity of Nigella sativa oil and its constituent, thymoquinone, against gastric mucosal injury induced by ischaemia/reperfusion in rats. $J$ Ethnopharmacol 2003; 84: 251-258.

6. Daba MH, Abdel-Rahman MS. Hepatoprotective activity of thymoquinone in isolated rat hepatocytes. Toxicol Lett 1998; 95: 23-29.

7. Raza M, Alghasham AA, Alorainy MS, El-Hadiyah TM. Beneficial interaction of thymoquinone and sodium valproate in experimental models of epilepsy: reduction in hepatotoxicity of valproate. Sci. Pharm. 2006; 74:159-173.

8. Gullett NP, Ruhul Amin AR, Bayraktar S, Pezzuto JM, Shin DM, Khuri FR, Kucuk O. Cancer prevention with natural compounds, Semin Oncol 2010; 37: 258-281.

9. Attoub S, Sperandio O, Raza H, Arafat K, Al-Salam S, Al Sultan MA, Al Safi M, Takahashi T, Adem A. Thymoquinone as an anticancer agent: Evidence from inhibition of cancer cells viability and invasion in vitro and tumor growth in vivo. Fundam Clin Pharmacol. 2012; 27: 557-569.

10. Banerjee Sanjeev; Parasramka Mansi; Sarkar, Fazlul H; Mohammad, Ramzi M. Diet and Cancer. Netherlands Springer Netherlands; 2012. $83 p$

11. Woo CC, Loo SY, Gee V, Yap CW, Sethi G, Kumar AP, Benny Tan KH. Anticancer activity of thymoquinone in breast cancer cells: possible involvement of PPARY pathway. Biochem Pharmacol 2011; 82: 464-475.

12. Khader M, Bresgen N, Eckl PM. In vitro toxicological properties of thymoquinone. Food Chem Toxico 2009; 47: 129-133.

13. Hanene JH, Karima R, Aya M, Salwa AE, Touhami M. Oxidative and genotoxic effects of Thymoquinone, Nigella sativa active compound, in Balb/c mice. Afr. J. Food Sci 2012; 6: 529-534.

14. El-Mahdy MA, Zhu Q, Wang QE, Wani G, Wani $A A$ Thymoquinone induces apoptosis through activation of caspase-8 and mitochondrial events in p53-null myeloblastic leukemia HL-60 cells. Int. J. Cancer 2005; 117: 409-417.

15. Naga MA, El-Aziz M. AA, Zeid SM, Daba sM. HY, ElGamal NK. Amelioration of Doxorubicin-induced genotoxicity in isolated cultured human lymphocytes by Thymoquinone. App Sci Report 2013; 4:210-218.
16. Singh NP, McCoy MT, Tice RR, Schneider EL. A simple technique for quantitation of low levels of DNA damage in individual cells. Exp Cell Res 1988; 175: 184-191.

17. Kumar AP, Quake AL, Chang KX, Zhou T, Lim SY, Singh $R$., Clément MV. Repression of NHE1 expression by PPARY activation is a potential new approach for specific inhibition of the growth of tumor cells in vitro and in vivo. Cancer Res 2009; 69: 8636-8644.

18. Gülkaç MD, Akpinar G, Üstün $H$, Kanli AÖ. Effects of vitamin $A$ on doxorubicin-induced chromosomal aberrations in bone marrow cells of rats. Mutagenesis. 2004; 19:231-236.

19. Shi M, Xu B, Azakami K, Morikawa T, Watanabe K, Morimoto K, Takeuchi T. Dual role of vitamin $C$ in an oxygen-sensitive system: Discrepancy between DNA damage and dell death. Free Radic Res 2005; 39: 213-220.

20. Khader M, Eckl PM, Bresgen N. Effects of aqueous extracts of medicinal plants on MNNG-treated rat hepatocytes in primary cultures. J Ethnopharmacol 2007; 112: 199-202.

21. Nagi MN, Mansour MA. Protective effect of thymoquinone against doxorubicin-induced cardiotoxicity in rats: $A$ possible mechanism of protection. Pharmacol Res 2000; 41: 283-289.

22. Monks TJ, Jones DC. The metabolism and toxicity of quinones, quinonimines, quinone methides, and quinone-thioethers. Curr Drug Metab 2002; 3: 425438.

23. Nagi MN, Almakki HA. Thymoquinone supplementation induces quinone reductase and glutathione transferase in mice liver: possible role in protection against chemical carcinogenesis and toxicity. Phytother Res 2009, 23: 1295-1298.

24. Suddek GM, Ashry NA, Gameil NM. Thymoquinone attenuates cyclophosphamide-induced pulmonary injury in rats. Inflammopharmacology 2013; 21: 427435.

25. Guo W, Reigan $P$, Siegel D, Ross D. Enzymatic reduction and glutathione conjugation of benzoquinone ansamycin heat shock protein 90 inhibitors: relevance for toxicity and mechanism of action. Drug Metab Dispos. 2008, 36: 2050-2057.

26. Khalife $K H$, Lupidi $G$. Non enzymatic reduction of thymoquinone in physiological conditions, Free Radic. Res. 2007, 41: 153-161.

27. Nagi MN, Al-Shabanah OA, Hafez MM. Sayed-Ahmed M. Thymoquinone supplementation attenuates cyclophosphamide-induced cardiotoxicity in rats. J Biochem Mol Toxicol 2011, 25: 135-142.

28. Greggi Antunes, Lusania M, Takahashi CS. Protection and induction of chromosomal damage by vitamin $C$ in human lymphocyte cultures. Teratog Carcinog Mutagen 1999; 19: 53-59. 